\title{
Ideological and Political Research on Curriculum from the Perspective of Ideological Management in Colleges and Universities
}

\author{
Yang Wang* \\ Henan Finance University, Zhengzhou 451464, Henan, China. \\ E-mail: 260790371@qq.com
}

\begin{abstract}
With the acceleration of globalization, there are more and more cultural exchanges and collisions between different regions and countries, and the social ideological contradictions between them are highlighted. At the same time, with the development of network information technology and the acceleration of cultural transmission, China's social ideology management is facing great challenges. As the main position for the construction of social ideology, ideological and political curriculum is an important means of ideological management in colleges and universities, so the ideological and political research under the ideological management of colleges and universities has very important practical significance. This paper analyzes and summarizes the current situation and existing problems of ideological and political work in colleges and universities from the perspective of ideological management.
\end{abstract}

Keywords: colleges and universities; ideological management; ideology and politics curriculum;

In the report of the 19th National Congress of the Communist Party of China, it is pointed out that "ideology determines the direction and development path of culture", and the ideological independence of a country is a manifestation of strong cultural soft power. With the vigorous development of China's socialist economy, we must not lag behind in cultural and political aspects, so as to our country's comprehensive national strength and international competitiveness will become stronger and stronger. At the request of the party, " building a socialist ideology with strong cohesive force and leading force ". Colleges and universities are the main position in the construction of socialist ideology. The period of students is the germination and active period of our consciousness, so it is easier to carry out management and construction. Secondly, college students are the future builders and successors of socialism with Chinese characteristics, practitioners of the rejuvenation of the Chinese nation, and strong supporters of realizing the Chinese dream. Therefore, the management of ideological form in Colleges and universities is the focus of social ideological management ${ }^{[1]}$. As an important means of ideological construction in colleges and universities, ideological and political curriculum is particularly important. This paper analyzes and summarizes the current status and problems of ideological and political work in colleges and universities from the perspective of ideological management ${ }^{[2]}$.

\section{Ideological management work in colleges and universities}

\subsection{Challenges faced by ideological construction in colleges and universities}

With the acceleration of globalization trend, there are more and more cultural exchanges and collisions between different countries and regions. China's social ideology has been impacted; "imported culture" and "western popularity" have affected the ideological establishment of college students to a certain extent. At present, China is in a period of rapid economic development and social transformation. Social thoughts are diversified and various thoughts are surging. For example, "utilitarianism" and "money worship" have a great impact on the thoughts of college teachers and students, affecting their outlook on life and values. In addition, with the rapid development of new media on the Internet, information transmission is fast, and the "love to see" fast food culture has a great impact on the establishment of values of teachers and students, which leads to their diverse ideas, weak beliefs, and even behavioral deviation. College Students' outlook on life and values are still in the initial stage of formation, vulnerable to the influence of non mainstream ideas, thinking and behavior swing. Therefore, ideological work in colleges and universities is facing a severe test ${ }^{[3]}$.

Copyright @ 2020 Yang Wang

doi: $10.18282 /$ le.v9i6.1307

This is an open-access article distributed under the terms of the Creative Commons Attribution Non-Commercial License

(http://creativecommons.org/licenses/by-nc/4.0/), which permits unrestricted non-commercial use, distribution, and reproduction in any medium, provided the original work is properly cited. 


\subsection{Ideological management in colleges and universities}

The school should attach great importance to ideological management, and the Party committee should give full play to its leading role. We should adhere to the socialist orientation of running schools and hold high the banner and firm our faith, so as to strengthen the construction of the Marxist front and strengthen the "Four Consciousness" as well as strengthen the "four self-confidence", and resolutely achieve the "two maintenance". We should carry out the national education policy and always keep in mind the educational task of "cultivating morality and cultivating people". At the same time, college teachers should strengthen the construction of sense of responsibility and bottom line thinking, strictly grasp the education discipline and spread positive energy to carry forward the main theme. At the same time, college teachers should firmly adhere to the Marxist position and not only teach by example, but also truly guide students to establish healthy and upward socialist values. In addition, under the guidance of socialist core values, we should make full use of external conditions to create a good campus cultural atmosphere and manage the field of network ideology, so as to strengthen public opinion monitoring, with timely and effective refutation and correction of wrong ideas ${ }^{[4]}$.

\section{An overview of ideological and political curriculum in colleges and Universities}

Since 2004, the central government has issued a number of documents related to ideological and political education, and then the exploration and practice of ideological and political education across the country has gradually taken shape. By 2014, Shanghai took the lead in putting forward the concept of "ideological and political curriculum" and began a series of reform and exploration. In recent years, the research on ideological and political curriculum is emerging in an endless stream, including theoretical aspects and the construction path of ideological and political curriculum aspects related research and analysis ${ }^{[5]}$. Among them, liberal arts fields focus on theoretical explanation of connotation and value origin of ideological and political curriculum while science and engineering fields such as medicine and health focus on the construction path and implementation elements of ideological and political curriculum.

Ideological and political curriculum education belongs to a kind of education concept. In line with the purpose of "educating people", from the perspective of national ideology strategy, the implementation of teaching and educating people is the main channel of classroom teaching. It is to integrate ideological and political education into all kinds of courses, including ideological and political theory courses, general education courses, professional courses, etc., in order to enhance political consciousness education and ideological value guidance. Through their own ideological and political education ability, college teachers integrate the socialist core values into the curriculum teaching, that is, combining the ideological and political education theory with the professional courses of various disciplines, guiding students to establish the correct, upward, values and outlook on life of their own, so as to achieve all-round, whole process and subtle influence on education.

\section{Construction path for ideological and political curriculum under ideological management}

\subsection{Implementation of Party committee's main responsibility}

The Party committee of the university gives full play to the core leadership role and provides policy support for the practice of Ideological and political education from the aspects of direction guidance, curriculum design, plan implementation and constraint mechanism. In addition, we should improve the responsibility mechanism and implement relevant policies. From top to bottom, the Party committee of the college grasps the direction to carry out the top-level design; secondly, the party committees of all colleges organize the overall coordination and implementation; finally, the Party branches, Party members and teachers carry out specific operation and implementation.

\subsection{Construction of teaching staff}

Teachers' ability and level of Ideological and political education determine the effect of ideological and political curriculum education. The cultivation of teachers' teaching ability for ideological and political is the inevitable choice of ideological construction in colleges and universities. Teachers should consciously and continuously strengthen theoretical knowledge learning and improve their ideological level and ideological and political ability of the curriculum, as well as constantly innovate and improve teaching methods. In addition, the school set up relevant training lectures or courses for teachers to carry out professional training, and set up a certain supervision and assessment system to test teachers' ideological and political teaching ability. 


\subsection{Curriculum design and development}

The development and design of curriculum is the prerequisite for the implementation of Ideological and political education. We should make full use of modern network information technology, fully and deeply excavate the ideological and political education resources, so as to achieve the connection between the classroom and the course as well as optimize the design of the ideological and political teaching content. First of all, we should make full use of the characteristics of various disciplines and explore the ideological and political elements contained in the professional courses to realize the coordination between the professional courses and the ideological and political curriculums; secondly, we should effectively integrate the ideological and political teaching and professional curriculums teaching. After the relationship between the ideological and political elements and the contents of the professional curriculums is clarified, the ideological and political elements can be integrated with the professional course by stages, levels and order through the curriculum design, so that the content of professional courses and ideological and political curriculums promote each other; finally, it is necessary to ensure the correctness and practicability of the ideological and political content and keep up with the development trend of the times. We should constantly enrich the ideological with political elements in the professional courses, and fully collect students' ideas, network materials, etc., to identify, select and integrate them, so as to speed up the revision and development of the course content ${ }^{[6]}$.

\subsection{Do a good job in the quality management for ideological and political curriculums}

The construction of ideological and political curriculum education needs not only teachers' team ability, but also perfect quality monitoring system and evaluation standards to control the ideological and political education.。 First of all, we should improve the quality standards of the ideological and political education of the curriculum, including the conditions of the curriculum, the standard of the construction of the teaching staff, the standard of the teaching quality and the evaluation standard ${ }^{[7]}$; secondly, we should carry out the evaluation regularly and solve the problems existing in the ideological and political construction of the curriculum, so as to continuously improve the quality of the ideological and political education of the curriculum.

\section{Conclusion}

To sum up, colleges and universities are the main position of China's social ideological construction, and college students are the vanguard of "building a socialist ideology with strong cohesion and leading force". Under the construction and management of ideology in colleges and universities, the reform and innovation of ideological and political education in colleges and universities is imperative.

\section{References}

1. Dong Qingtao. Research on College Students' Management Innovation from the Perspective of Ideological and Political Management. Research and Practice of Innovation and Entrepreneurship Theory ,2020,3(10):149-150.

2. Chen Chunhua. On the Collaborative Management of College Students' Political Ideology and Network Public Opinion under the Security of Political Ideology__ On the Innovation of College Students' Ideological and Political Education from the Perspective of New Media. Chemical Reagents,2020,42(02):223

3. Wang Lijuan, Ding Xiangzhen, Zheng Rui etc. Teaching Assistant Led Group Discussion Mode and Innovation Research on "Ideological and Political Curriculum" Education in Colleges and Universities. Education and Teaching Forum, 2020(11).

4. Zhang Xiang.Thinking on the Integration of Socialist Core Values into the Construction of Campus Cultural Ecology__ Taking the Education of Red Cultural Resources Innovation Socialist Core Values in Zhude Memorial Hall as An Example. Journal of Hubei Institute of Economics: Humanities and Social Sciences,2020(3):10-13.

5. Jiao Fuxwei. Research on the Teaching Reform of Calligraphy General Courses in Colleges and Universities under the Concept of " Ideological and Political Curriculum "__-Taking the Public Course of Calligraphy in Longnan Teachers College as An Example. Journal of Urumqi Vocational University, 2019(4):43-45.

6. Hou Huiqin, Journalist of the editorial. The Basic Experience of New China's Mainstream Ideology Construction (2)_-Interview with Professor Hou Huiqin, Secretary of the Party committee of the Institute of Marxism, Chinese Academy of Social Sciences. Guide to ideological and theoretical education,2009(9):18-23. 